\title{
Effect of circulating exosomes from transition cows on Madin-Darby bovine kidney cell function
}

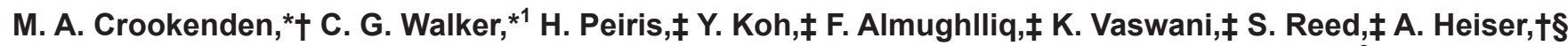 \\ J. J. Loor,\# J. K. Kay,\| S. Meier,\| S. S. Donkin, П A. Murray,† V. S. R. Dukkipati,† J. R. Roche,॥² \\ and M. D. Mitchell \\ *DairyNZ, Auckland 1010, New Zealand \\ †Institute of Vet, Animal, and Biomedical Sciences, Massey University, Palmerston North 4442, New Zealand \\ fUniversity of Queensland, Centre for Clinical Research, Herston, Queensland 4029, Australia \\ $\S A g R e s e a r c h$, Hopkirk Research Institute, Palmerston North 4442, New Zealand \\ \#Department of Animal Sciences, University of Illinois, Urbana 61801 \\ IIDairyNZ, Hamilton 3284, New Zealand \\ IDepartment of Animal Science, Purdue University, West Lafayette, IN 47907
}

\begin{abstract}
The greatest risk of metabolic and infectious disease in dairy cows is during the transition from pregnancy to lactating (i.e., the transition period). The objective of this experiment was to determine the effects of extracellular vesicles (microvesicles involved in cell-tocell signaling) isolated from transition cows on target cell function. We previously identified differences in the protein profiles of exosomes isolated from cows divergent in metabolic health status. Therefore, we hypothesized that these exosomes would affect target tissues differently. To investigate this, 2 groups of cows ( $\mathrm{n}=5 /$ group) were selected based on the concentration of $\beta$-hydroxybutyrate and fatty acids in plasma and triacylglycerol concentration in liver at wk 1 and 2 postcalving. Cows with high concentrations of $\beta$-hydroxybutyrate, fatty acids, and triacylglycerol were considered at increased risk of clinical disease during the transition period (high-risk group; $\mathrm{n}=5$ ) and were compared with cows that had low concentrations of the selected health indicators (low-risk group; $\mathrm{n}=5$ ). At 2 time points during the transition period (postcalving at wk 1 and 4), blood was sampled and plasma exosomes were isolated from the high-risk and low-risk cows. The exosomes were applied at concentrations of 10 and $1 \mu \mathrm{g} / \mathrm{mL}$ to $5 \times 10^{3}$ Madin-Darby bovine kidney cells grown to $50 \%$ confluence in 96 -well plates. Results indicate a numerical increase in cell proliferation when exosomes from high-risk cows were applied compared with those from low-risk cows. Consistent with an effect on cell proliferation, quantitative reverse transcriptase

Received October 13, 2016.

Accepted March 5, 2017.

${ }^{1}$ Current address: Growing Up in New Zealand, University of Auckland Tamaki Campus, Auckland 1072, New Zealand.

${ }^{2}$ Corresponding author: john.roche@dairynz.co.nz
\end{abstract}

PCR indicated a trend for upregulation of 3 proinflammatory genes (granulocyte colony-stimulating factor, ciliary neurotrophic factor, and CD27 ligand) with the application of high-risk exosomes, which are involved in cellular growth and survival. Proteomic analysis indicated 2 proteins in the low-risk group that were not identified in the high-risk group (endoplasmin and catalase), which may also be indicative of the metabolic state of origin. It is likely that the metabolic state of the transition cow affects cellular function through exosomal messaging; however, more in-depth research into cross-talk between exosomes and target cells is required to determine whether exosomes influence Madin-Darby bovine kidney cells in this manner.

Key words: transition cow, metabolic disease, extracellular vesicle

\section{INTRODUCTION}

Exosomes are extracellular vesicles that contain proteins, mRNA, and microRNA (miRNA) and are transported in blood as long-distance, intercellular messengers. They are biomarkers of metabolic or disease state (Distler et al., 2006; Taylor and Gercel-Taylor, 2008; Crookenden et al., 2016a), and their effect on target tissues is influenced by the physiological state of the secreting cell (Théry et al., 2009; Mathivanan et al., 2010). For example, tumor-derived exosomes contain a different protein cargo than exosomes secreted from nonmalignant cells (Andre et al., 2002). Furthermore, proteomic investigation of bovine exosomes has suggested that these nanoparticles are important for lactation physiology and mammary immune function and as indicators of metabolic health (Reinhardt et al., 2013; Crookenden et al., 2016a).

The transition to lactation in dairy cows is associated with metabolic and physiological stress as well as 
altered immune function (Drackley, 1999; Sordillo and Raphael, 2013; Crookenden et al., 2016b). During this period there is a high incidence of inflammatory disorders, such as mastitis and endometritis, which negatively affect milk production and reproductive function (LeBlanc et al., 2002a,b; Halasa et al., 2007). However, the degree of physiological and immunological stress in early lactation varies among cows (Heiser et al., 2015; Crookenden et al., 2016b). We have previously identified differences in the protein cargo of exosomes from dairy cows divergent in fertility (Mitchell et al., 2016) and metabolic health status over the transition period (Crookenden et al., 2016a). We further hypothesized that differences in exosomal cargo evident in cows divergent in metabolic health have integral roles in regulating the physiology of important tissues (e.g., liver) via intercellular cross-talk.

To investigate this hypothesis, exosomes were isolated from the plasma of cows with divergent indicators of metabolic health during the transition period. To assess the action of these exosomes on target cells, they were cocultured in vitro with Madin-Darby bovine kidney (MDBK) cells, which have been established as a model system for aspects of bovine liver cell metabolism (Bionaz et al., 2008; Thering et al., 2009; White et al., 2012; Zhou et al., 2015).

\section{MATERIALS AND METHODS}

\section{Animals}

The Ruakura Animal Ethics Committee (Hamilton, New Zealand) approved all animal manipulations (RAEC\#12799) in accordance with the New Zealand Animal Welfare Act (Ministry of Primary Industries, 1999). The parent experiment was undertaken at Scott Farm (Hamilton, New Zealand; $37^{\circ} 46^{\prime} \mathrm{S} 175^{\circ} 18^{\prime} \mathrm{E}$ ) between July and October 2013.

Cows previously identified as having either a high risk $(\mathrm{n}=5)$ or a low risk $(\mathrm{n}=5)$ of metabolic dysfunction based on blood plasma fatty acids (FA; mmol/L), BHB (mmol/L), and liver triacylglycerol (\% liver wet weight) during the 2 wk immediately after calving were used for this study. The classification of these cows has been described previously (Crookenden et al., 2016a). Briefly, the high-risk cows had greater $(P<0.01)$ values for the 3 variables compared with cows in the low-risk category during wk 1 (d $4 \pm 2)$ and wk $2(\mathrm{~d} 11 \pm 2)$ postcalving. Values for high-risk cows versus low-risk cows were 1.80 versus $0.66 \pm 0.32,1.00$ versus $0.45 \pm 0.25$, and 9.0 versus $1.8 \pm 1.59$ for $\mathrm{FA}, \mathrm{BHB}$, and triacylglycerol, respectively, during wk 1 postcalving and 1.20 versus $0.30 \pm 0.33,0.86$ versus $0.48 \pm 0.11$, and 10.3 versus $1.4 \pm 1.59$ during wk 2 postcalving (mean $\pm \mathrm{SE}$ of the difference). Average milk yield $(P<0.05)$, percentage fat $(P=0.2)$, and percentage protein $(P<0.05)$ during wk 1 and 2 of lactation were $23.6 \mathrm{~kg}, 5.0 \%$, and $3.9 \%$, respectively, for the high-risk group and $18.4 \mathrm{~kg}, 4.2 \%$, and $4.2 \%$, respectively, for the low-risk group.

Blood samples for exosome isolation (wk 1 and 4) were collected by coccygeal venipuncture into evacuated blood tubes containing EDTA anticoagulant. Blood was immediately placed on ice and centrifuged at 1,500 $\times g$ for $12 \mathrm{~min}$ at $4^{\circ} \mathrm{C}$, and the plasma was aspirated and stored at $-20^{\circ} \mathrm{C}$ until assayed.

\section{Exosome Isolation}

The workflow used for the isolation of exosomes is presented in Figure 1. Exosomes were isolated from plasma $(2 \mathrm{~mL})$ at wk 1 and 4 by ultracentrifugation as previously described (Salomon et al., 2014; Sarker et al., 2014). Briefly, plasma was diluted 1:1 with PBS $(\mathrm{pH}$ 7.4) and centrifuged at $12,000 \times g$ for $30 \mathrm{~min}$ at $4^{\circ} \mathrm{C}$ (Sorvall high-speed microcentrifuge, fixed rotor angle $=900$; Thermo Fisher Scientific Inc., Asheville, NC). The resulting supernatant $(2 \mathrm{~mL})$ was filtered $(0.2 \mu \mathrm{m}), 8 \mathrm{~mL}$ of PBS ( $\mathrm{pH} 7.4)$ was added, and the solution was centrifuged at $100,000 \times g$ for $120 \mathrm{~min}$ at $4^{\circ} \mathrm{C}$ (Sorvall T-8100 fixed-angle ultracentrifuge rotor; Thermo Fisher Scientific Inc.). The supernatant was then carefully removed, $300 \mu \mathrm{L}$ of PBS was added, and the pellet (extracellular vesicle) was resuspended. A discontinuous OptiPrep gradient (Sigma-Aldrich, Castle Hill, NSW, Australia) was used to isolate exosomes from the total extracellular vesicle. The gradient was made by diluting a stock solution of OptiPrep (60\% wt/vol) with $0.25 M$ sucrose-10 n $M$ Tris ( $\mathrm{pH} 7.5$ ) to make 40\% (wt/vol), 20\% (wt/vol), 10\% (wt/vol), and $5 \%$ (wt/vol) solutions that were carefully layered, and the sample was placed on top. Tubes were centrifuged in an ultracentrifuge swinging bucket rotor (SW40 Ti Rotor, Beckman Coulter, Australia Pty. Ltd., Lane Cove, NSW, Australia) at $100,000 \times g$ for $20 \mathrm{~h}$ at $4^{\circ} \mathrm{C}$. Fractions from each sample gradient $(12 \times 1 \mathrm{~mL})$ were removed and washed in ultracentrifuge tubes (Sorvall; Thermo Fisher Scientific Inc.) by adding $9 \mathrm{~mL}$ of PBS and centrifuging at $100,000 \times g$ for $2 \mathrm{~h}$ at $4^{\circ} \mathrm{C}$. The resulting supernatant was discarded, and the exosome pellets from each of the 12 fractions were resuspended in $50 \mu \mathrm{L}$ of $\mathrm{PBS}$ and stored at $-20^{\circ} \mathrm{C}$ until further analysis.

\section{Validation of Exosome Isolation}

The density of each fraction was measured in a control OptiPrep gradient tube by determining the absorbance at $244 \mathrm{~nm}$ (Spectrostar Nano microplate 
reader, BMG Labtech, Mornington, Victoria, Australia). The density of each fraction was calculated from absorbance readings, and exosomes were expected at 1.12 to $1.19 \mathrm{~g} / \mathrm{mL}$ (Schröder et al., 1997; Tauro et al., 2012). Exosomes were characterized by size distribution using a NanoSight NS500 instrument (NanoSight NTA version 2.3 Nanoparticle Tracking and Analysis Release Version Build 0033, NanoSight Ltd., Wiltshire,
UK) as previously described in Salomon et al. (2014) and Sarker et al. (2014; Supplementary Figure S1; https://doi.org/10.3168/jds.2016-12152). Western blot was used to verify the presence of endocytic markers TSG101 (1:500; sc-6037, Santa Cruz Biotechnology, Dallas, TX) and CD63 (1:1,000; EXOAB-CD63A-1, System Biosciences, Palo Alto, CA; Théry et al., 2006; Koh et al., 2016).

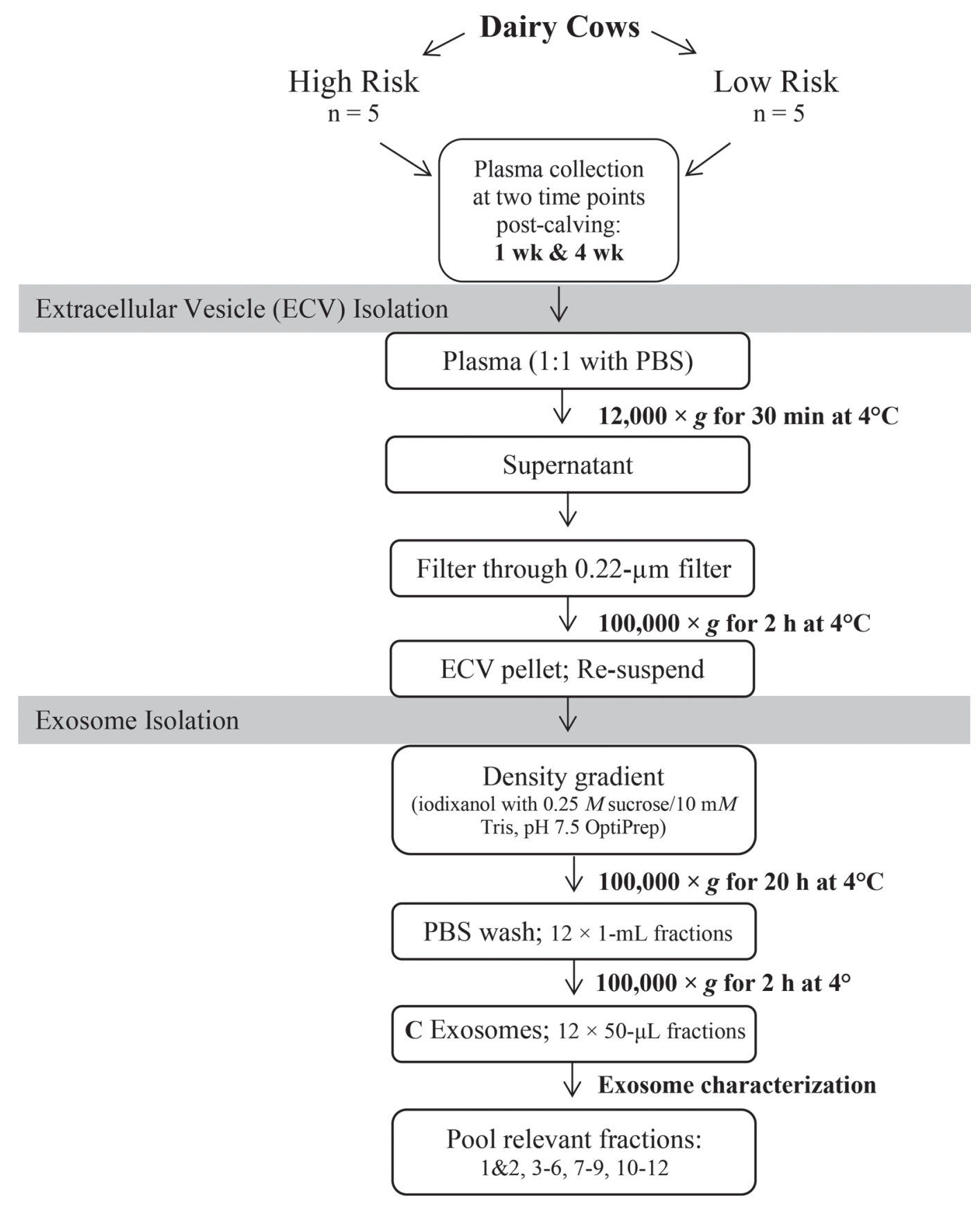

Figure 1. Workflow for the isolation of exosomes from bovine plasma in high-risk and low-risk cows. OptiPrep: Sigma-Aldrich, Castle Hill, NSW, Australia. 


\section{Exosome Coculture}

Epithelial (MDBK) cells were obtained from the American Type Culture Collection (Manassas, VA) and cultured as described previously (Bionaz et al., 2008; Thering et al., 2009). Five thousand cells per well were plated on 96 -well plates and grown at $37^{\circ} \mathrm{C}$ and $5 \%$ $\mathrm{CO}_{2}$ for $24 \mathrm{~h}$ in $100 \mu \mathrm{L} /$ well of Dulbecco's modified Eagle medium (DMEM; Thermo Fisher Scientific Inc.) supplemented with $5 \%$ fetal bovine serum (FBS; Bovogen, Interpath Services Pty Ltd., Heidelberg West, Victoria, Australia) and 1\% antibiotic, antimycotic solution (10,000 $\mathrm{U}$ of penicillin, 10,000 $\mathrm{g}$ of streptomycin, and $25 \mathrm{~g}$ of amphotericin B/mL; Gibco, Thermo Fisher Scientific) to achieve $50 \%$ confluency before treatment exposure. Upon $50 \%$ confluence, cells were incubated
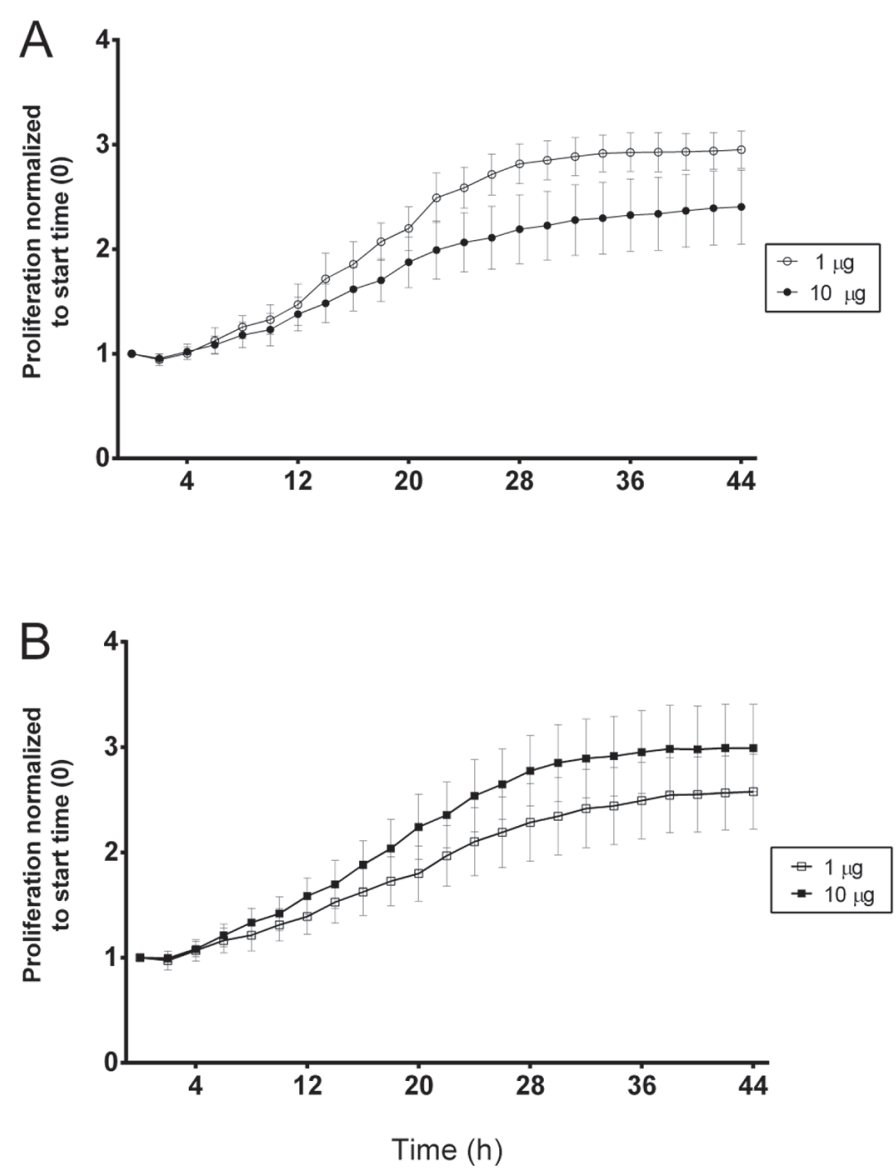

Figure 2. IncuCyte (Essen BioScience, Ann Arbor, MI) proliferation data of Madin-Darby bovine kidney cocultures with exosome fractions 3 to 6. (A) Exosomes isolated at wk 1 from low-risk cows at $1 \mu \mathrm{g} /$ $\mathrm{mL}$ concentration (open circles) and $10 \mu \mathrm{g} / \mathrm{mL}$ concentration (filled circles). (B) Exosomes isolated at wk 1 from high-risk cows at $1 \mu \mathrm{g} /$ $\mathrm{mL}$ concentration (open squares) and $10 \mu \mathrm{g} / \mathrm{mL}$ concentration (filled squares). Results are presented as means at each time point \pm SEM; $n$ $=5$. There was no interaction between dose, time, and risk group $(P$ $>0.05)$. However, the effect of dose was most evident at 24 to $40 \mathrm{~h}(P$ $<0.05)$ in the low-risk group. The dose of exosomes isolated at wk 4 did not affect proliferation $(P>0.05$; data not shown). for $40 \mathrm{~h}$ in DMEM supplemented with $5 \%$ exosomedepleted FBS plus exosome treatments or controls. Exosome-depleted FBS was prepared using ultracentrifugation (Sorvall, Thermo Fisher Scientific) at 10,000 $\times g$ for $20 \mathrm{~h}$ at $4^{\circ} \mathrm{C}$. All treatments $(10$ or $1 \mu \mathrm{g} / \mathrm{mL}$ of exosomal protein from fractions 3 to 6 and 7 to 9 ) were applied in triplicate in 3 preparations of MDBK cells. Negative controls included DMEM supplemented with PBS $(10 \mu \mathrm{L})$, FBS $(10 \mu \mathrm{L})$, and exosome-depleted FBS $(10 \mu \mathrm{L})$. Cell proliferation and morphology were analyzed using the IncuCyte Live-Cell Imaging system (Essen BioScience, Ann Arbor, MI), which uses highdensity phase contrast real-time cell imaging as a proliferation parameter (Salomon et al., 2013; Koh et al., 2016). Images of cell proliferation were acquired every 2 $\mathrm{h}$ for the duration of the experiment (Figures 2 and 3).

After $40 \mathrm{~h}$ of exosome treatment, the cell culture media were collected, and technical triplicates were pooled and stored at $-20^{\circ} \mathrm{C}$ for ELISA analysis. The cells and exosome coculture from each well were collected using $200 \mu \mathrm{L}$ of RLT lysis buffer (Qiagen, Hilden, Germany) with $1 \% \beta$-mercaptoethanol per well. Technical triplicates were pooled and stored at $-80^{\circ} \mathrm{C}$ for subsequent RNA and protein extraction.

\section{RNA Extraction}

Cell lysates were homogenized by passing through a 25 -gauge needle attached to a $1-\mathrm{mL}$ sterile syringe at least 15 times. Total RNA was extracted from cell homogenates using a Qiagen RNeasy Mini kit according to the manufacturer's instructions. An on-column DNA digest was used to remove genomic DNA (Qiagen). The RNA was eluted in $20 \mu \mathrm{L}$ of DNase-/RNase-free water by completing 2 elutions of $10 \mu \mathrm{L}$. The quantity and purity of RNA was determined by spectrophotometry using a Nanodrop ND-1000 (Nanodrop Technologies, Wilmington, DE) and stored at $-80^{\circ} \mathrm{C}$ until further analysis.

\section{cDNA Synthesis and Gene Expression Analysis}

Total RNA (400 ng) was reverse transcribed using the $\mathrm{RT}^{2}$ HT First Strand Kit (Qiagen). Reversetranscriptase negative controls were also generated by excluding the enzyme, and cDNA samples were stored at $-20^{\circ} \mathrm{C}$. The bovine $\mathrm{RT}^{2}$ Profiler PCR Array was used to quantify the gene expression of chemokines and cytokines by reverse-transcriptase quantitative PCR (PABT-150ZC-24; Qiagen). The PCR arrays were cycled using the following parameters: $1 \times\left(95^{\circ} \mathrm{C}\right.$ for $10 \mathrm{~min})$ followed by $40 \times\left(95^{\circ} \mathrm{C}\right.$ for $15 \mathrm{~s}$ and $60^{\circ} \mathrm{C}$ for 1 min) cycles using the ABI StepOne machine (Applied Biosystems, Foster City, CA). The endogenous control 
genes included on the array were $\beta$-actin $(A C T B)$, TATA box binding protein $(T B P), G A P D H$, and hypoxanthine phosphoribosyltransferase 1 (HPRT1). Gene expression was normalized to the endogenous control gene HPRT1 using the cycle threshold $(\Delta \Delta \mathrm{Ct})$ method because this gene was the most stably expressed across all treatments. Gene expression results were generated for wk 1 coculture samples. The data for cocultures of both fractions (3-6 and 7-9) were combined for gene expression analysis to determine the difference between high-risk and low-risk exosome cocultures.

\section{Protein Extraction}

Total protein from cells was extracted using acetone precipitation from the protein fraction that flows through the column during the RNA binding step of the RNA extraction. Four volumes $(4.8 \mathrm{~mL})$ of ice-cold acetone was added to the flow-through in $15-\mathrm{mL}$ Corning tubes and incubated overnight at $-20^{\circ} \mathrm{C}$. Samples were centrifuged for $10 \mathrm{~min}$ at $13,000 \times \mathrm{g}$, air dried, and resuspended in $100 \mu \mathrm{L}$ of $50 \mathrm{~m} M$ ammonium bicarbonate $(\mathrm{pH} 8.5)$. Protein was stored at $-20^{\circ} \mathrm{C}$ pending mass spectrometry analysis.

\section{MS Analysis}

Coculture samples chosen for liquid chromatography (LC)/MS were based on IncuCyte and gene expression results; MDBK cocultured with exosomes isolated from wk 1 plasma using fractions 3 to 6 were chosen for proteomic analysis. These coculture samples were considered the most physiologically relevant because the cows were at their most metabolically divergent at
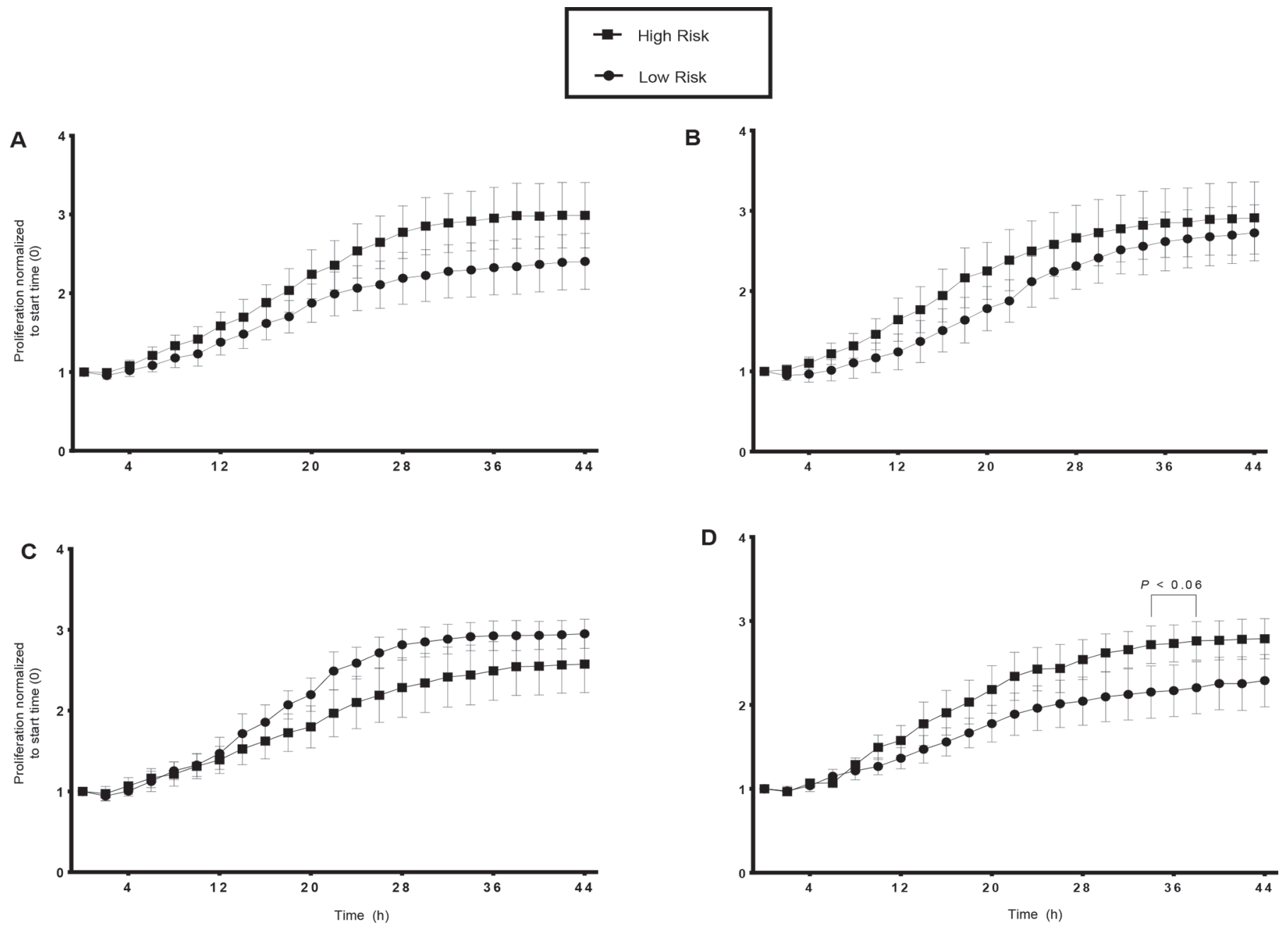

Figure 3. IncuCyte (Essen BioScience, Ann Arbor, MI) proliferation data of Madin-Darby bovine kidney cocultures with exosome fractions 3 to 6. (A) Exosomes isolated at wk $1(10 \mu \mathrm{g} / \mathrm{mL}$ concentration). (B) Exosomes isolated at wk 4 (10 $\mu \mathrm{g} / \mathrm{mL}$ concentration). (C) Exosomes isolated at wk $1(1 \mu \mathrm{g} / \mathrm{mL}$ concentration). (D) Exosomes isolated at wk $4(1 \mu \mathrm{g} / \mathrm{mL}$ concentration). Results are presented as means at each time point \pm SEM; $\mathrm{n}=5$. 
this time point. Total protein from these samples was sonicated for $15 \mathrm{~min}$ and reduced with dithiothreitol for $1 \mathrm{~h}$. Proteins were then alkylated in $10 \mathrm{~m} M$ iodoacetic acid for $1 \mathrm{~h}$ in the dark. The samples were diluted to 1:10 with $50 \mathrm{~m} M$ ammonium bicarbonate and digested with trypsin $(20 \mu \mathrm{g})$ at $37^{\circ} \mathrm{C}$ for $18 \mathrm{~h}$. The samples were then desalted by solid phase extraction using a STAGE tip protocol (stop and go extraction tips for matrixassisted laser desorption and ionization, nanoelectrospray, and LC/MS sample pretreatment in proteomics; Rappsilber et al., 2003). The eluted peptides were dried by centrifugal evaporation to remove acetonitrile and redissolved in Solvent A (0.1\% formic acid in water). The resulting peptide mixture was analyzed by LCMS/MS on a 5600 Triple TOF mass spectrometer (AB Sciex, Framingham, MA) equipped with an Eksigent Nanoflow binary gradient HPLC system (Dublin, CA) and a nanospray III ion source. The MS/MS spectra were collected using information dependent acquisition with a survey scan $(m / z=350-1,500)$ followed by 12 data-dependent product ion scans of the 12 most intense precursor ions. All mass spectra were analyzed using the MASCOT search engine (www.matrixscience. com) and ProteinPilot (AB Sciex) against the Swissprot database with the species set as bovine (http:// www.ebi.ac.uk/uniprot/download-center). Positive identifications were ascribed where MASCOT scores were $>30$. False discovery rate was estimated using a reversed sequence database.

Peptide information from ProteinPilot (version 4.5, AB Sciex) was used to calculate the relative abundance of proteins within the data set. Data were quality trimmed by removing peptides with an unused score of $<0.5$, a contribution score of 0 , and a confidence score of $<50$. Mass accuracy (ppm error) was calculated using the equation

$$
\text { ppm error }=(\mathrm{dMass} / \text { Prec MW }) \times 1,000,000,
$$

where dMass $=$ the observed value from mass spectrometer and Prec MW = the theoretical value calculated from periodical table. Peptides were retained if $\mathrm{ppm}$ error was between -20 and 20 . The relative abundance of proteins within a sample was calculated by summing the peptide intensity (PrecursorSignal) for a given protein and dividing by the total peptide intensity of that sample:

$$
\begin{gathered}
\text { relative abundance }(\%)= \\
(\text { sum of PrecursorSignal of a given protein } / \\
\text { sum of total PrecursorSignal) } \times 100 .
\end{gathered}
$$

\section{Statistics}

To test the effect of risk category and dose of exosomes on MDBK cell proliferation during the course of the coculture experiment, both an area under the curve analysis for cellular kinetics and a linear mixed model analysis were used (SAS 9.3; SAS Institute, Cary, NC). The linear mixed model included the fixed effects of risk category, dose, and time of acquisition and their interactions and the random effect of animals. The covariance error structure for repeated measures over time points within animals in each risk category was determined using Akaike information criterion. A first-order autoregressive model was found to be the most appropriate error structure. The distribution of proliferation data was tested for normality using Shapiro-Wilk, Kolmogorov-Smirnov, and AndersonDarling tests, and the residuals of data were found to be normally distributed. An unpaired $t$-test was used to determine the effect of risk (low-risk and high-risk coculture samples) on expression of genes as quantified by reverse-transcriptase quantitative PCR. The arithmetic mean and standard deviation of relative protein abundance was calculated for the control, low-risk, and high-risk coculture samples. If a peptide signal was not detected, a numerical placeholder of $0.01 \%$ was entered. Relative protein abundance was analyzed using a 2-sample $t$-test (PROC MIXED, SAS 9.3), and significance was declared if $P<0.05$ (Supplementary Table S1; https://doi.org/10.3168/jds.2016-12152).

\section{RESULTS AND DISCUSSION}

The aim of this experiment was to investigate whether exosomes isolated from cows different in their metabolic state during the peripartum period affected the proliferation and function of MDBK cells. Proliferation data of MDBK cells treated with exosomes are presented in Figures 2 and 3. Gene expression data and LC-MS/MS proteomics results are presented in Figures 4, 5, and 6 and Supplementary Table S1 (https://doi. org/10.3168/jds.2016-12152). The results indicate that protein changes may be associated with cow risk category; 40 and 15 unique proteins were identified in the low-risk and high-risk samples, respectively (Figure 5). There tended to be an effect of exosome concentration on proliferation in the low-risk cows at wk 1 in which cells treated with $1 \mu \mathrm{g}$ of exosomes exhibited faster growth at 24 to $40 \mathrm{~h}$ compared with cells treated with $10 \mu \mathrm{g}$ of exosomes (Figure 2). There was no effect $(P>$ 0.05) of risk category on MDBK cell proliferation (Figure 3), cytokine gene expression (Figure 4), or protein abundance (Figure 6). However, sufficient differences 
A

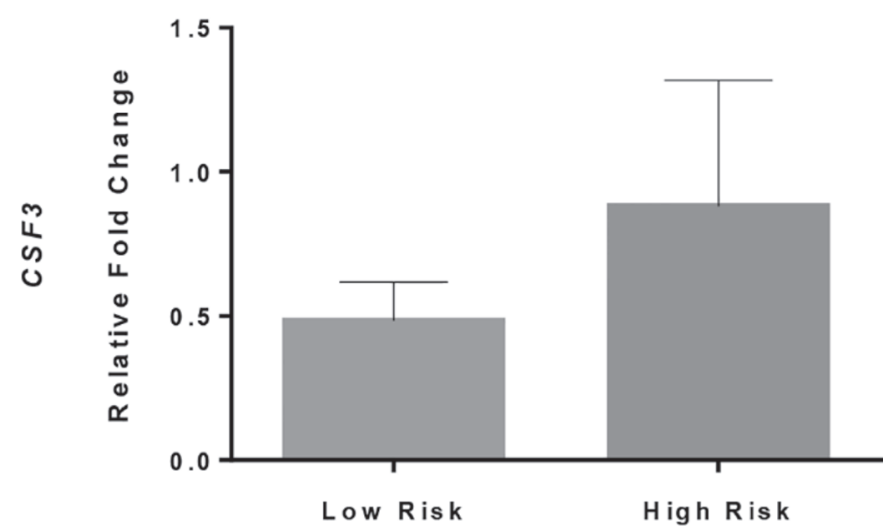

B

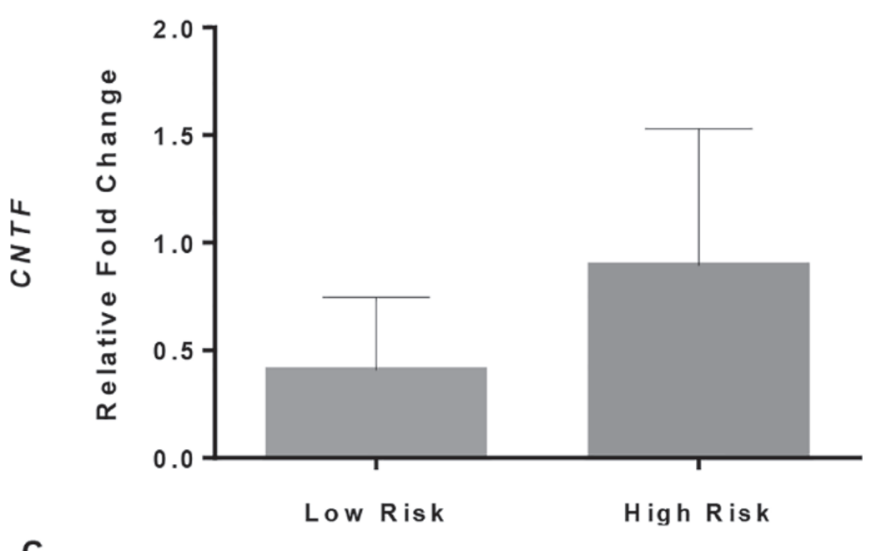

C

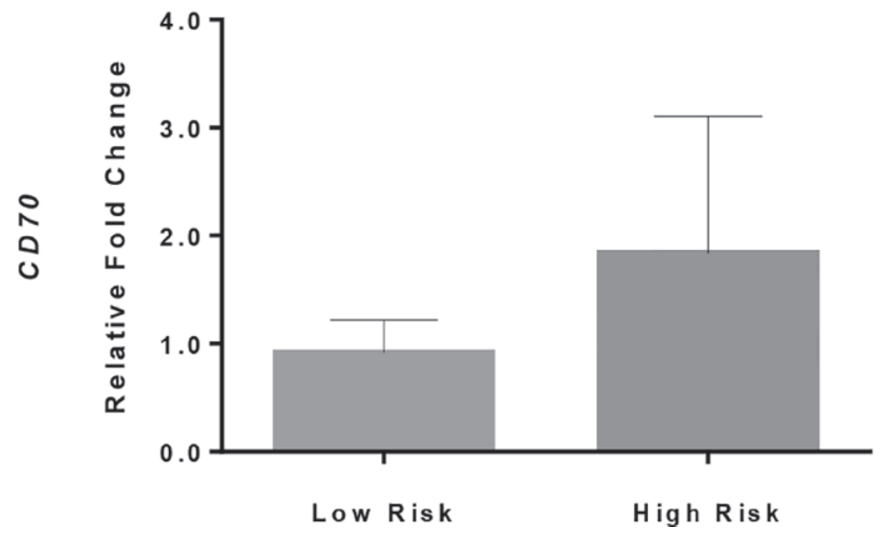

Figure 4. Gene expression results of high-risk and low-risk coculture models at wh 1 data from cocultures of both pooled fractions (3-6 and 7-9) combined]. (A) Granulocyte colony-stimulating factor (CSF3; $P=0.10)$. (B) Ciliary neurotrophic factor $(C N T F ; P=0.09)$. (C) CD27 ligand $\left(C D^{70} ; P=0.14\right)$. Gene expression is normalized to endogenous control hypoxanthine phosphoribosyltransferase 1 using the cycle threshold $(\Delta \Delta \mathrm{Ct})$ method. Results are presented as means $\pm \mathrm{SEM} ; \mathrm{n}=5$. indicate an effect of exosome source on the cellular physiology of MDBK cells (Figure 5). Further research with greater numbers of cows is required to determine the effect of metabolic state on exosome messaging of target tissues.

\section{IncuCyte Results}

The high-risk cows were selected based on indicators of liver dysfunction (excessive FA mobilization and a failure to fully oxidize FA, which led to increased BHB production and the accumulation of FA in liver). Such a metabolic profile would be expected to generate systemic and tissue-specific inflammation (Ohtsuka et al., 2001; Sordillo and Mavangira, 2014). A previous study investigating the protein cargo of the exosomes used in the current study indicated differences between these treatment groups supporting such an effect (Crookenden et al., 2016a).

Initial analyses support the hypothesis that the metabolic state of the cow may differentially alter cell proliferation. The MDBK cells treated with low-risk exosomes at wk 1 (Figure 2) tended to demonstrate lower proliferation $(P>0.05)$ when exosomes were applied at the largest dose $(10 \mu \mathrm{g}$ compared with $1 \mu \mathrm{g})$. Furthermore, a numerical $(P>0.05)$ increase in cell proliferation occurred in the high-risk cows compared with the low-risk cows when applied at $10-\mu \mathrm{g}$ concen-

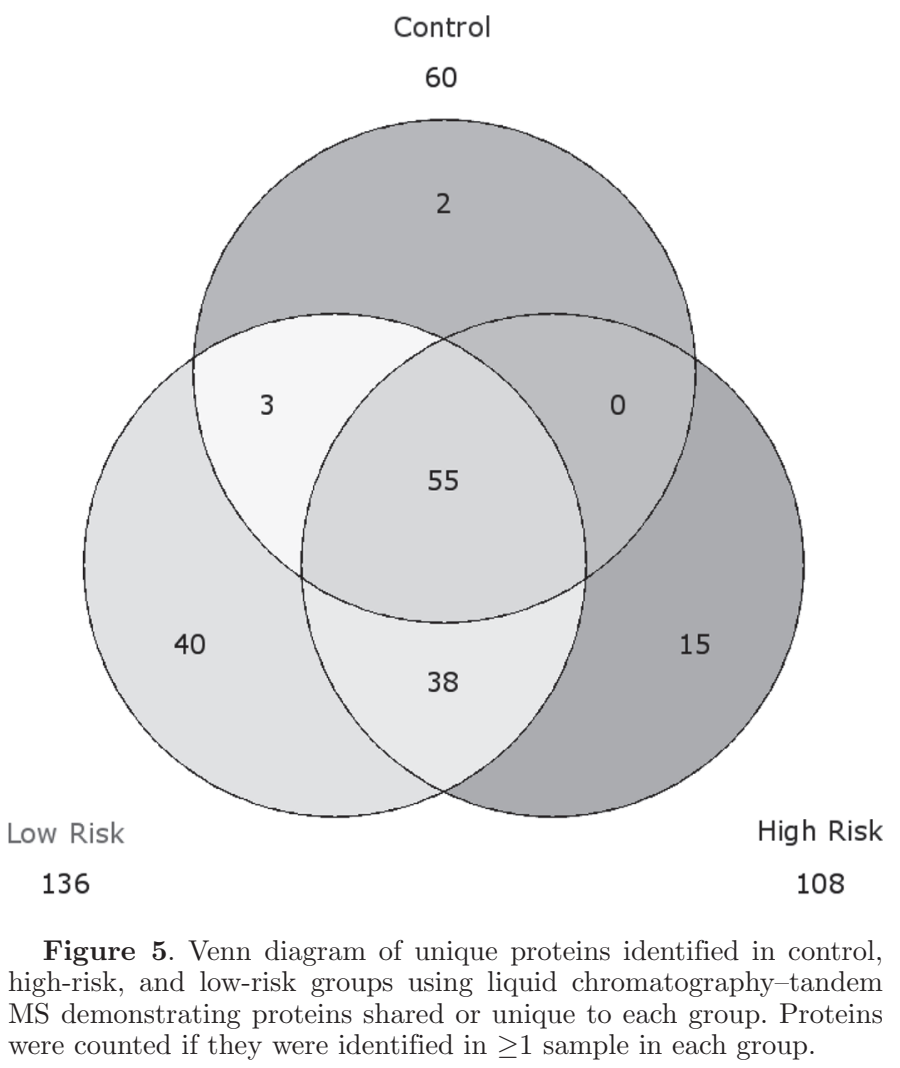


tration (Figure 3). The lower rate of proliferation with the application of more low-risk exosomes (Figure 2) is consistent with Aucher et al. (2013), who demonstrated that exosome-derived miRNA is capable of inhibiting target cell proliferation. The low-risk exosomes were isolated from cows with a reduced inflammatory phenotype and may carry miRNA specific to this. Recent research suggests that exosomal miRNA could be used to treat metabolic disease (Thomou et al., 2017). Labeling of exosomal contents to track transfer of exosomal contents into target cells should be considered in future experiments (Lai et al., 2015). Although limited by the low numbers of animals in the current study, results indicate that the peripartum metabolic state of the dairy cow likely affects the influence that exosomes have on cell function.

Furthermore, the numerical differences in proliferation between the high-risk and low-risk cocultures are consistent with published studies that indicate that proinflammatory conditions increase cellular proliferation. The conditions of nonalcoholic fatty liver disease and nonalcoholic steatohepatitis are characterized by hepatic inflammation and FA accumulation in the liver (Hardy et al., 2016) - characteristics similar to those reported in high-risk cows in the experiment described here and in Crookenden et al. (2016a). Our previous study reported that the exosomal protein cargo was influenced by the metabolic state of the high-risk cows, which was proinflammatory in nature (Crookenden et al., 2016a). Consistent with this, exosomes isolated from a primary hepatocyte culture model of nonalcoholic steatohepatitis were proinflammatory and could induce inhibition of cell apoptosis (Hirsova et al., 2016). Therefore, it was hypothesized that exosomes isolated from divergent risk groups would result in differences in MDBK cell proliferation. It is possible that the exosomes isolated from the high-risk and low-risk cows are not programmed to target MDBK cells due to their kidney origin or that the nonclinical fatty liver disease in early-lactation dairy cows may not alter proliferation of kidney cells. Additionally, the exosomes isolated from blood represent a composite of release from all tissues that may serve to dilute any liver-specific changes in exosome released for the high-risk and low-risk cows tested here. Nevertheless, the results presented indicate no significant effect of the metabolic state of the exosome donor cows on the proliferation of MDBK cells despite a numerical difference in cellular proliferation in favor of the high-risk treatment.

\section{Gene Expression Results}

The cytokine and chemokine PCR array identified 32 genes that meet cycle threshold cut-offs $(<30)$ for gene expression quantification. Of these, no significant differences in gene expression were found between high-risk and low-risk exosome coculture samples. However, 3 genes tended to be increased in the high-risk coculture samples compared with the low-risk samples (Figure 4). These were the genes encoding granulocyte colony-stimulating factor $(C S F 3 ; P<0.10)$, ciliary neurotrophic factor $(C N T F ; P<0.10)$, and CD27 ligand $\left(C D^{70} ; P=0.14\right)$, all of which were upregulated in the high-risk cows relative to the low-risk cows.

Granulocyte colony-stimulating factor is an important survival and proliferation factor of neutrophils (Basu et al., 2002) that can act on neuronal cells as a neurotrophic factor to induce neurogenesis and inhibit apoptosis (Schneider et al., 2005). Interestingly, this is the same function as the protein product of the gene $C N T F$, the expression of which also tended to be increased in high-risk coculture samples. The similar functions of these 2 genes in cellular proliferation support numerical differences presented in Figure 3. MDBK cells are an epithelial-like cell line. The 3 genes that tended to be upregulated in the high-risk coculture samples are all expressed in the thymic epithelium (Haynes et al., 2000; Coquet et al., 2013). The epithelial cells of the thymus express several cytokines for T-lymphocyte development and confer immunotolerance to self-antigens. Other epithelial cells have a capacity for immunomodulation as they provide the first barrier against foreign invaders (Rescigno et al., 2008; Malvisi et al., 2016); therefore, MDBK cells may have some capacity for immunomodulation. Conversely, these genes may be indicative of the exosomal tissue of origin and could reflect mRNA from the thymus. This is a limitation of the coculture model, and one that requires further investigation. The tendency for differences in gene expression between the high-risk and low-risk cultures potentially indicates altered immune function and support for the numerical differences in proliferation (Figure 3) by exosomes from cows in the high-risk category for metabolic dysfunction; however, further investigation is required to confirm this.

\section{Proteomics Results}

The results of the protein analysis are presented in Table 1, Figures 5 and 6, and Supplementary Table S1 (https://doi.org/10.3168/jds.2016-12152). Unique proteins were identified between cells treated with plasma exosomes isolated from high-risk and low-risk cows. These differences may be indicative of the metabolic state of the cows from which they were derived; however, extensive changes were not evident. Two of the unique proteins identified in the low-risk group ( $\geq 2$ cows) and not identified in the high-risk group were endoplasmin 


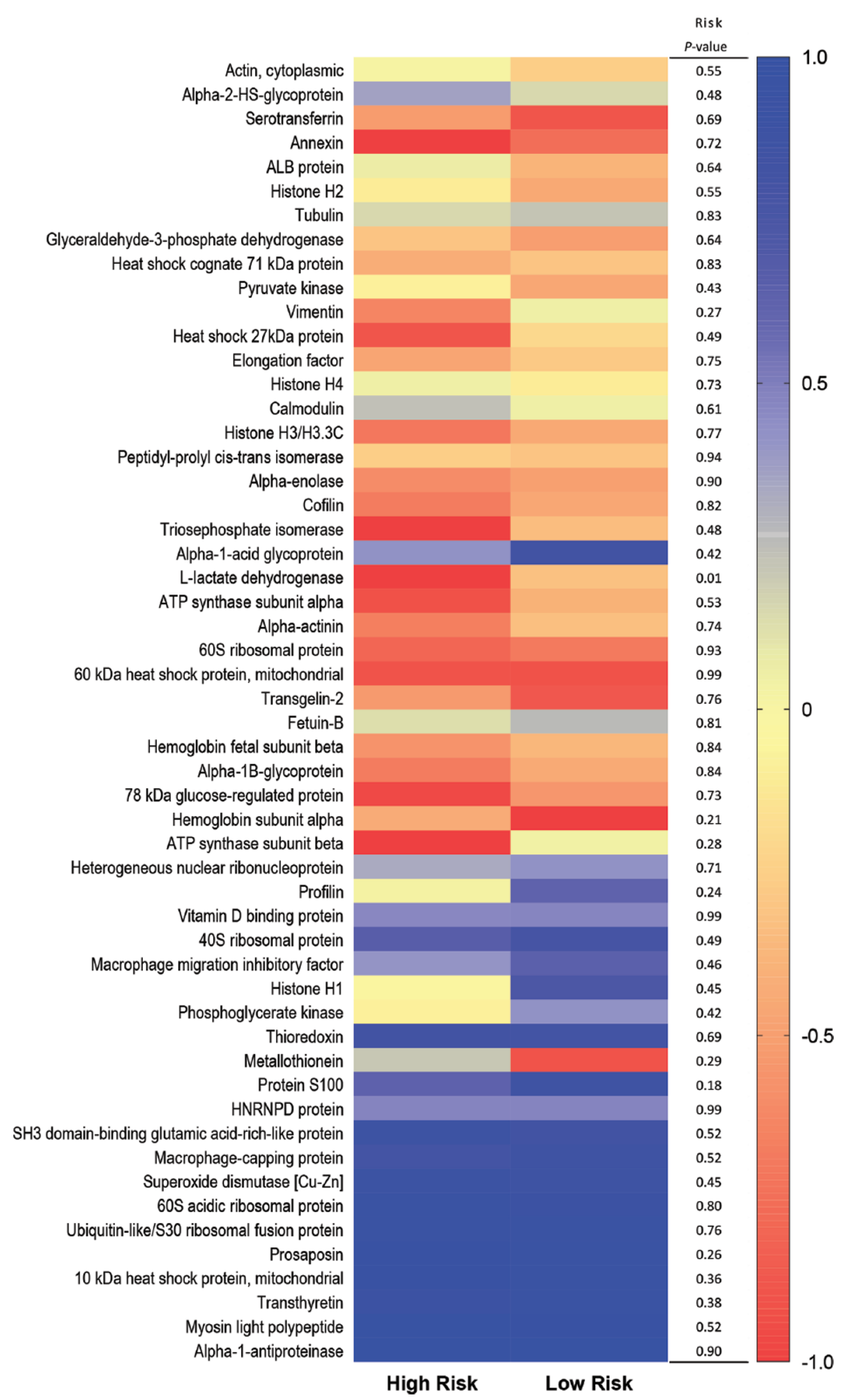

Figure 6. Heat map of proteins identified in high-risk and low-risk coculture samples by liquid chromatography-tandem MS. Relative abundance of proteins is the sum of peptide signals for a given protein as a percentage of the total peptide signal for that sample. Proteins presented are those identified in $\geq 50 \%$ of cows in both risk groups. The order of proteins is based on abundance of protein within the control sample, with the most abundant at the top. Results are presented as a ratio relative to the protein abundance in the control sample whereby a ratio of 0 indicates the same abundance as the control, $>0$ (blue) indicates a greater abundance compared with the control, and $<0$ (orange-red) indicates a lower abundance compared with the control. The $P$-value for the effect of risk, analyzed using a 2-sample $t$-test (PROC MIXED, SAS 9.3, SAS Institute Inc., Cary, NC), is included next to the heat map. 
Table 1. Unique proteins and representative accession number of proteins identified in control, high-risk, and low-risk groups using liquid chromatography-tandem $\mathrm{MS}^{1}$

\begin{tabular}{|c|c|}
\hline Accession no. & Protein name \\
\hline \multicolumn{2}{|c|}{ Common to all groups } \\
\hline A4ZZF8 & $\alpha$-Actinin \\
\hline A5PJ79 & Transketolase \\
\hline A6H6Y0 & HNRNPD protein \\
\hline B0JYL8 & Cofilin \\
\hline B0JYN3 & L-Lactate dehydrogenase \\
\hline B0JYN6 & $\alpha$-2-HS-glycoprotein \\
\hline B0JYQ0 & ALB protein \\
\hline E1BH22 & Histone H2A \\
\hline E1BHA5 & 40S ribosomal protein S19 \\
\hline E1BHJ0 & Profilin \\
\hline E9RHW1 & Heat shock $27-\mathrm{kDa}$ protein \\
\hline F1MB08 & $\alpha$-Enolase \\
\hline F1MLB8 & ATP synthase subunit $\alpha$ \\
\hline F1MPU0 & Clathrin heavy chain \\
\hline F1MUZ9 & $60-\mathrm{kDa}$ heat shock protein, mitochondrial \\
\hline F1N6C0 & Calmodulin \\
\hline G3MZ21 & Hemoglobin fetal subunit $\beta$ \\
\hline G3N2P2 & Histone $\mathrm{H} 3.3 \mathrm{C}$ \\
\hline G3X6N3 & Serotransferrin \\
\hline G3X807 & Histone H4 \\
\hline G8JKZ8 & Thioredoxin \\
\hline I6YIV1 & Annexin A2 \\
\hline I7CT57 & Vitamin $\mathrm{D}$ binding protein \\
\hline O18787 & Elongation factor $1 \alpha$ \\
\hline P01966 & Hemoglobin subunit $\alpha$ \\
\hline P02253 & Histone H1.2 \\
\hline P10096 & Glyceraldehyde-3-phosphate dehydrogenase \\
\hline P19120 & Heat shock cognate $71 \mathrm{kDa}$ protein \\
\hline P21752 & Thymosin $\beta-10$ \\
\hline $\mathrm{P} 48616$ & Vimentin \\
\hline P60712 & Actin, cytoplasmic \\
\hline P62935 & Peptidyl-prolyl cis-trans isomerase A \\
\hline P63103 & $14-3-3$ protein \\
\hline P81947 & Tubulin $\alpha-1 \mathrm{~B}$ chain \\
\hline Q0QEM9 & ATP synthase subunit $\beta$ \\
\hline Q0QEV5 & Ribosomal protein L18 \\
\hline Q0VCX2 & 78-kDa glucose-regulated protein \\
\hline Q2KJF1 & $\alpha$-1B-glycoprotein \\
\hline Q2VYC3 & Eukaryotic translation elongation factor $1 \beta$ \\
\hline Q3SYT9 & Poly(RC) binding protein 2 \\
\hline Q3SZN8 & Ribonuclease/angiogenin inhibitor \\
\hline Q3T087 & $60 \mathrm{~S}$ ribosomal protein \\
\hline Q3T0P6 & Phosphoglycerate kinase \\
\hline Q3ZC44 & Heterogeneous nuclear ribonucleoprotein A/B \\
\hline Q3ZC87 & Pyruvate kinase \\
\hline Q3ZCH0 & Stress-70 protein, mitochondrial \\
\hline Q58D62 & Fetuin-B \\
\hline Q5E956 & Triosephosphate isomerase \\
\hline Q5E9F5 & Transgelin-2 \\
\hline Q5GN72 & $\alpha$-1-acid glycoprotein \\
\hline Q6PVY3 & Macrophage migration inhibitory factor \\
\hline Q862H7 & Protein S100 \\
\hline Q862Q2 & Similar to ribosomal protein S3 \\
\hline Q8MII4 & Metallothionein \\
\hline Q9BGI4 & Peroxiredoxin \\
\hline \multicolumn{2}{|c|}{ Common to exosome treatment } \\
\hline A6QPM9 & PTMS protein \\
\hline E1B9K1 & Polyubiquitin-C \\
\hline E1BCL5 & $60 \mathrm{~S}$ acidic ribosomal protein $\mathrm{P} 1$ \\
\hline E1BF20 & HNRNPH1 \\
\hline F1MCT8 & SYNCRIP \\
\hline F1MMK9 & Protein AMBP \\
\hline F1MXP8 & Prosaposin \\
\hline F1N169 & FLNA \\
\hline F1N3A1 & Thrombospondin-1 \\
\hline
\end{tabular}


Table 1 (Continued). Unique proteins and representative accession number of proteins identified in control, high-risk, and low-risk groups using liquid chromatography-tandem $\mathrm{MS}^{1}$

\begin{tabular}{|c|c|}
\hline Accession no. & Protein name \\
\hline F1N647 & Fatty acid synthase \\
\hline G3X6S5 & SH3 domain-binding glutamic acid-rich-like protein \\
\hline O46375 & Transthyretin \\
\hline P00442 & Superoxide dismutase $[\mathrm{Cu}-\mathrm{Zn}]$ \\
\hline P13696 & Phosphatidylethanolamine-binding protein \\
\hline P34955 & $\alpha$-1-antiproteinase \\
\hline P60661 & Myosin light polypeptide 6 \\
\hline P61603 & $10-\mathrm{kDa}$ heat shock protein, mitochondrial \\
\hline P62866 & Ubiquitin-like/S30 ribosomal fusion protein \\
\hline P68002 & Voltage-dependent anion-selective channel protein \\
\hline Q2HJH9 & Programmed cell death protein \\
\hline Q3B7M5 & LIM and SH3 domain protein \\
\hline Q3SYU2 & Elongation factor \\
\hline Q3SZ57 & $\alpha$-Fetoprotein \\
\hline Q3SZ65 & Eukaryotic initiation factor $4 \mathrm{~A}-\mathrm{II}$ \\
\hline Q3T0Q4 & Nucleoside diphosphate kinase B \\
\hline Q3T0Q6 & Cellular nucleic acid-binding protein \\
\hline Q3T165 & Prohibitin \\
\hline Q3ZBA4 & RNA binding motif (RNP1, RRM) protein \\
\hline Q3ZBH0 & T-complex protein 1 subunit $\beta$ \\
\hline Q3ZBS7 & VTN \\
\hline Q3ZBT1 & Transitional endoplasmic reticulum ATPase \\
\hline Q3ZBZ8 & Stress-induced-phosphoprotein \\
\hline Q5E9E2 & Myosin regulatory light polypeptide \\
\hline Q5EAD2 & D-3-phosphoglycerate dehydrogenase \\
\hline Q7SIH1 & $\alpha$-2-Macroglobulin \\
\hline Q862P4 & Similar to elongation factor-1-gamma \\
\hline Q865V6 & Macrophage-capping protein \\
\hline V6F9A2 & Apolipoprotein A-I preproprotein \\
\hline \multicolumn{2}{|c|}{ Common to low risk and control } \\
\hline A5D7E8 & Protein disulfide-isomerase \\
\hline G8JL04 & Thymosin $\beta 4$ X-linked \\
\hline $\mathrm{Q} 95 \mathrm{M} 18^{2}$ & Endoplasmin \\
\hline \multicolumn{2}{|c|}{ Unique to low risk } \\
\hline A0JNP8 & LOC516032 protein \\
\hline A4IFI0 & IGLL1 protein \\
\hline A5PJE3 & Fibrinogen $\alpha$ chain \\
\hline A6QLL8 & Fructose-bisphosphate aldolase \\
\hline A6QNL5 & PDIA6 protein \\
\hline A8E641 & DPYSL5 protein \\
\hline B0JYP6 & IGK protein \\
\hline E1B925 & ARID1A \\
\hline E1BNF9 & SLAMF9 \\
\hline E1BQ37 & SFPQ \\
\hline F1MAV0 & Fibrinogen $\beta$ chain \\
\hline F1MDH3 & TLN1 \\
\hline F1MY44 & HNRNPM \\
\hline F1N301 & RPL22 \\
\hline F1N6D5 & 116-kDa U5 small nuclear ribonucleoprotein \\
\hline G3X7A5 & Complement C3 \\
\hline G3X8D6 & Iodothyronine deiodinase \\
\hline $\mathrm{P} 00432^{2}$ & Catalase \\
\hline P07589 & Fibronectin \\
\hline $\mathrm{P} 12234$ & Phosphate carrier protein, mitochondrial \\
\hline P16116 & Aldose reductase \\
\hline P28801 & Glutathione S-transferase P \\
\hline P35705 & Thioredoxin-dependent peroxide reductase, mitochondrial \\
\hline P81644 & Apolipoprotein A-II \\
\hline Q0IIL9 & Receptor protein-tyrosine kinase \\
\hline Q0QF29 & Malate dehydrogenase \\
\hline Q1RMN8 & Immunoglobulin light chain, lambda gene cluster \\
\hline Q2HJH4 & HNRPDL protein \\
\hline Q2KJH6 & Serpin $\mathrm{H} 1$ \\
\hline Q3MHY1 & Cysteine and glycine-rich protein \\
\hline Q3SZ20 & Serine hydroxymethyltransferase, mitochondrial \\
\hline Q3SZ62 & Phosphoglycerate mutase \\
\hline
\end{tabular}


Table 1 (Continued). Unique proteins and representative accession number of proteins identified in control, high-risk, and low-risk groups using liquid chromatography-tandem MS $^{1}$

\begin{tabular}{ll}
\hline Accession no. & Protein name \\
\hline Q3SZZ9 & FGG protein \\
Q3T0B6 & Complement component 1 Q subcomponent-binding protein \\
Q3T0E0 & Copper transport protein ATOX1 \\
Q3T101 & IGL@ protein \\
Q3ZBF7 & Prostaglandin E synthase \\
Q5E9B7 & Chloride intracellular channel protein \\
Q8SQH5 & ADP/ATP translocase \\
V6F832 & Alpha-crystallin B chain \\
Unique to high risk & Aldo-keto reductase family 1, member B1 \\
Q5E962 & Ribosomal protein L23a Y-linked protein \\
S5G966 & Tubulin-specific chaperone A \\
P48427 & Ubiquitin-60S ribosomal protein L40 \\
P63048 & SERPINE1 mRNA binding protein \\
A1L5B7 & SET nuclear oncogene \\
Q2TBR3 & Ubiquitin-40S ribosomal protein S27a \\
P62992 & CCDC88A \\
G3MXG3 & Guanine nucleotide-binding protein \\
P63243 & Lactoferrin \\
B9VPZ5 & Barrier-to-autointegration factor \\
P61283 & HLA-B-associated transcript \\
Q861P7 & MAGEB4 \\
G5E5F7 & Nucleophosmin \\
F1MTV9 & Nucleosome assembly protein 1-like \\
A6H767 & \\
Unique to control & FRYL \\
E1BKE1 & G3N131 \\
G3N131 &
\end{tabular}

${ }^{1}$ Proteins were counted if they were identified in $\geq 1$ sample in each group.

${ }^{2}$ Protein was identified in $\geq 50 \%$ of cows in a particular risk group and $0 \%$ in the other risk group.

(gp96) and catalase. Endoplasmin is a chaperone protein with a key role in regulating folding of immune proteins and is therefore critical to immune function (Schild and Rammensee, 2000). This result supports previously discussed changes in gene expression related to immune regulation. Furthermore, recombinasemediated loss of endoplasmin in hepatocytes leads to decreased cellular activity and compromises liver function (Rachidi et al., 2015), highlighting an important role in metabolic health. Catalase activity has been described in microvesicles, where it acts as a scavenger of reactive oxygen species and protects against oxidative damage (Hulsmans and Holvoet, 2013). These results may indicate enhanced cellular function in MDBK cells treated with exosomes from low-risk cows. However, no substantial proteomic changes can be related to the divergent metabolic states from where the exosomes originated.

The proteomic data presented here are consistent with previous studies investigating exosomes. Relative abundance between risk groups did not reveal significant changes associated with metabolic risk category. Lactate dehydrogenase was the only protein greater $(P<0.05$; Supplementary Table S1; https:// doi.org/10.3168/jds.2016-12152) in low-risk cocultures compared with high-risk cocultures (calculated using relative protein abundance). Lactate dehydrogenase catalyzes the conversion of pyruvate to lactate with the regeneration of $\mathrm{NADH}$ to $\mathrm{NAD}^{+}$, which is essential in hypoxic and anaerobic conditions, and as a result is upregulated in such conditions (Alegre et al., 2015). Several other proteins involved in cellular metabolism that are frequently identified in exosomes were identified by proteomic analysis in the current study-for example, histone proteins ( $\mathrm{H} 2 \mathrm{~B}, \mathrm{H} 4$, and $\mathrm{H} 3.3$ ), annexin proteins (A2), cofilin 1, heat shock proteins $(60 \mathrm{kDa}, 70 \mathrm{kDa})$, 14-3-3 proteins (sigma, zeta/delta), phosphoglycerate kinase, and ATP synthase (Mathivanan et al., 2010; Welton et al., 2010). The proteins identified in the current study are consistent with exosome-related changes in target cell metabolism; however, there is no clear evidence that the changes are related to a metabolic state of exosomal origin.

\section{Limitations of the Study Design}

We acknowledge that the number of animals included in each risk category is low; therefore, the results need to be considered with caution. The number of animals in each risk group $(\mathrm{n}=5)$ was limited by the number of animals in the parent experiment $(\mathrm{n}=45)$. Only 10 cows had significantly divergent metabolic profiles at 
both wk 1 and 2 postcalving. Furthermore, exosomal protein isolated from the plasma samples was limited. Finally, only 2 concentrations of exosomes were used as a dose comparison ( 1 and $10 \mu \mathrm{g} / \mathrm{mL}$ ). Based on the results of the dose-response proliferation curves (Figure 2 ), it is possible that comparisons including more dose rates would reveal further changes.

The low concentration of protein from the exosome and MDBK cell coculture likely contributed to the variation in peptides revealed by LC-MS/MS. Improved methods for identification of low-abundance peptides may have revealed changes in protein expression of physiological importance (Kedia et al., 2015). This is a novel preliminary study; the presented results could be validated or extended with a bigger starting cohort of cows. However, we have generated the maximum data from the limited sample numbers available.

\section{CONCLUSIONS}

The current study investigated the effect of plasma exosomes from 2 groups of metabolically divergent cows on MDBK cell function. We conclude that only limited, nonsignificant changes in gene expression and protein expression were evident when MDBK cells were exposed to exosomes derived from cows with high or low risk of metabolic dysfunction. The functional changes were inconclusive in determining the risk category of origin. However, this study provides a foundation for future studies investigating cross-talk between exosomes and target cells in cows with subclinical health dysfunction during the transition period.

\section{ACKNOWLEDGMENTS}

The authors acknowledge the help of DairyNZ farm staff (Scott Farm, DairyNZ) and the statistical analysis and advice of Barbara Kuhn-Sherlock (DairyNZ). We also acknowledge the advice of Martin Middleditch (Mass Spectroscopy Centre, University of Auckland). This work was supported by funding from New Zealand dairy farmers through DairyNZ Inc., Hamilton, New Zealand (RD1403) and the Ministry of Business, Innovation, and Employment, Wellington, New Zealand (DRCX1201).

\section{REFERENCES}

Alegre, E., M. Sammamed, S. Fernández-Landázuri, L. Zubiri, and A. González. 2015. Circulating biomarkers in malignant melanoma. Adv. Clin. Chem. 69:47-89. https://doi.org/10.1016/ bs.acc.2014.12.002.

Andre, F., N. E. C. Schartz, M. Movassagh, C. Flament, P. Pautier, P. Morice, C. Pomel, C. Lhomme, B. Escudier, T. Le Chevalier, T. Tursz, S. Amigorena, G. Raposo, E. Angevin, and L. Zitvogel. 2002. Malignant effusions and immunogenic tumour-derived exosomes. Lancet 360:295-305. https://doi.org/10.1016/S01406736(02)09552-1.

Aucher, A., D. Rudnicka, and D. M. Davis. 2013. MicroRNAs transfer from human macrophages to hepato-carcinoma cells and inhibit proliferation. J. Immunol. 191:6250-6260. https://doi. org/10.4049/jimmunol.1301728.

Basu, S., G. Hodgson, M. Katz, and A. R. Dunn. 2002. Evaluation of role of G-CSF in the production, survival, and release of neutrophils from bone marrow into circulation. Blood 100:854-861. https://doi.org/10.1182/blood.V100.3.854.

Bionaz, M., C. R. Baumrucker, E. Shirk, J. P. Vanden Heuvel, E. Block, and G. A. Varga. 2008. Short communication: Characterization of Madin-Darby bovine kidney cell line for peroxisome proliferator-activated receptors: Temporal response and sensitivity to fatty acids. J. Dairy Sci. 91:2808-2813. https://doi.org/10.3168/ jds.2007-0789.

Coquet, J. M., J. C. Ribot, N. Bąbała, S. Middendorp, G. van der Horst, Y. Xiao, J. F. Neves, D. Fonseca-Pereira, H. Jacobs, D. J. Pennington, B. Silva-Santos, and J. Borst. 2013. Epithelial and dendritic cells in the thymic medulla promote CD4+Foxp3+ regulatory $\mathrm{T}$ cell development via the CD27-CD70 pathway. J. Exp. Med. 210:715-728. https://doi.org/10.1084/jem.20112061.

Crookenden, M. A., A. Heiser, A. Murray, V. S. R. Dukkipati, J. K. Kay, J. J. Loor, S. Meier, M. D. Mitchell, K. M. Moyes, C. G. Walker, and J. R. Roche. 2016a. Parturition in dairy cows temporarily alters the expression of genes in circulating neutrophils. J. Dairy Sci. 99:6470-6483. https://doi.org/10.3168/jds.2015-10877.

Crookenden, M. A., C. G. Walker, H. Peiris, Y. Koh, A. Heiser, J. J. Loor, K. M. Moyes, and A. Murray. 2016b. Short communication: Proteins from circulating exosomes represent metabolic state in transition dairy cows. J. Dairy Sci. 99:7661-7668. https://doi. org/10.3168/jds.2015-10786.

Distler, J. H. W., L. C. Huber, S. Gay, O. Distler, and D. S. Pisetsky. 2006. Microparticles as mediators of cellular cross-talk in inflammatory disease. Autoimmunity 39:683-690. https://doi. org $/ 10.1080 / 08916930601061538$.

Drackley, J. K. 1999. Biology of dairy cows during the transition period: The final frontier? J. Dairy Sci. 82:2259-2273. https://doi. org/10.3168/jds.S0022-0302(99)75474-3.

Halasa, T., K. Huijps, O. Østerås, and H. Hogeveen. 2007. Economic effects of bovine mastitis and mastitis management: A review. Vet. Q. 29:18-31. https://doi.org/10.1080/01652176.2007.9695224.

Hardy, T., F. Oakley, Q. M. Anstee, and C. P. Day. 2016. Nonalcoholic fatty liver disease: Pathogenesis and disease spectrum. Annu. Rev. Pathol. 11:451-496. https://doi.org/10.1146/annurevpathol-012615-044224.

Haynes, B. F., G. D. Sempowski, A. F. Wells, and L. P. Hale. 2000. The human thymus during aging. Immunol. Res. 22:253-261. https://doi.org/10.1385/IR:22:2-3:253.

Heiser, A., A. Mccarthy, N. Wedlock, S. Meier, J. Kay, C. Walker, M. A. Crookenden, M. D. Mitchell, S. Morgan, K. Watkins, J. J. Loor, and J. R. Roche. 2015. Grazing dairy cows had decreased interferon- $\gamma$, tumor necrosis factor, and interleukin-17, and increased expression of interleukin-10 during the first week after calving. J. Dairy Sci. 98:937-946. https://doi.org/10.3168/ jds.2014-8494.

Hirsova, P., S. H. Ibrahim, A. Krishnan, V. K. Verma, S. F. Bronk, N. W. Werneburg, M. R. Charlton, V. H. Shah, H. Malhi, and G. J. Gores. 2016. Lipid-induced signaling causes release of inflammatory extracellular vesicles from hepatocytes. Gastroenterology 150:956-967. https://doi.org/10.1053/j.gastro.2015.12.037.

Hulsmans, M., and P. Holvoet. 2013. MicroRNA-containing microvesicles regulating inflammation in association with atherosclerotic disease. Cardiovasc. Res. 100:7-18. https://doi.org/10.1093/cvr/ cvt161.

Kedia, K., C. A. Nichols, C. D. Thulin, and S. W. Graves. 2015. Novel "omics" approach for study of low-abundance, low-molecular-weight components of a complex biological tissue: Regional differences between chorionic and basal plates of the human placenta. Anal. Bioanal. Chem. 407:8543-8556. https://doi.org/10.1007/ s00216-015-9009-3. 
Koh, Y. Q., H. N. Peiris, K. Vaswani, S. Reed, G. E. Rice, C. Salomon, and M. D. Mitchell. 2016. Characterization of exosomal release in bovine endometrial intercaruncular stromal cells. Reprod. Biol. Endocrinol. 14:78. https://doi.org/10.1186/s12958-016-0207-4.

Lai, C. P., E. Y. Kim, C. E. Badr, R. Weissleder, T. R. Mempel, B. A. Tannous, and X. O. Breakefield. 2015. Visualization and tracking of tumour extracellular vesicle delivery and RNA translation using multiplexed reporters. Nat. Commun. 6:7029. https://doi. org/10.1038/ncomms8029.

LeBlanc, S. J., T. F. Duffield, K. E. Leslie, K. G. Bateman, G. P. Keefe, J. S. Walton, and W. H. Johnson. 2002a. The effect of treatment of clinical endometritis on reproductive performance in dairy cows. J. Dairy Sci. 85:2237-2249. https://doi.org/10.3168/ jds.S0022-0302(02)74303-8.

LeBlanc, S. J., T. F. Duffield, K. E. Leslie, K. G. Bateman, G. P. Keefe, J. S. Walton, and W. H. Johnson. 2002b. Defining and diagnosing postpartum clinical endometritis and its impact on reproductive performance in dairy cows. J. Dairy Sci. 85:2223-2236.

Malvisi, M., M. Stuknyte, G. Magro, G. Minozzi, A. Giardini, I. De Noni, and R. Piccinini. 2016. Antibacterial activity and immunomodulatory effects on a bovine mammary epithelial cell line exerted by nisin A-producing Lactococcus lactis strains. J. Dairy Sci. 99:2288-2296. https://doi.org/10.3168/jds.2015-10161.

Mathivanan, S., H. Ji, and R. J. Simpson. 2010. Exosomes: Extracellular organelles important in intercellular communication. J. Proteomics 73:1907-1920. https://doi.org/10.1016/j.jprot.2010.06.006.

Ministry of Primary Industries. 1999. New Zealand Animal Welfare Act. Part 6. Use of animals in research, testing, and teaching. Accessed Jan. 24, 2015. http://www.legislation.govt.nz/act/ public/1999/0142/latest/DLM49664.html

Mitchell, M. D., K. Scholz-Romero, S. Reed, H. N. Peiris, Y. Q. Koh S. Meier, C. G. Walker, C. R. Burke, J. R. Roche, G. Rice, and C. Salomon. 2016. Plasma exosome profiles from dairy cows with divergent fertility phenotypes. J. Dairy Sci. 99:7590-7601. https:// doi.org/10.3168/jds.2016-11060.

Ohtsuka, H., M. Koiwa, A. Hatsugaya, K. Kudo, F. Hoshi, N. Itoh, H. Yokota, H. Okada, and S. Kawamura. 2001. Relationship between serum TNF activity and insulin resistance in dairy cows affected with naturally occurring fatty liver. J. Vet. Med. Sci. 63:10211025. https://doi.org/10.1292/jvms.63.1021.

Rachidi, S., S. Sun, B. X. Wu, E. Jones, R. R. Drake, B. Ogretmen, A. Cowart, C. J. Clarke, Y. A. Hannun, G. Chiosis, B. Liu, and Z. Li. 2015. Endoplasmic reticulum heat shock protein gp96 maintains liver homeostasis and promotes hepatocellular carcinogenesis. J. Hepatol. 62:879-888. https://doi.org/10.1016/j.jhep.2014.11.010.

Rappsilber, J., Y. Ishihama, and M. Mann. 2003. Stop and go extraction tips for matrix-assisted laser desorption/ionization, nanoelectrospray, and LC/MS sample pretreatment in proteomics. Anal. Chem. 75:663-670. http://dx.doi.org/https://doi.org/10.1021/ ac026117i.

Reinhardt, T. A., R. E. Sacco, B. J. Nonnecke, and J. D. Lippolis. 2013. Bovine milk proteome: Quantitative changes in normal milk exosomes, milk fat globule membranes and whey proteomes resulting from Staphylococcus aureus mastitis. J. Proteomics 82:141-154. https://doi.org/10.1016/j.jprot.2013.02.013.

Rescigno, M., U. Lopatin, and M. Chieppa. 2008. Interactions among dendritic cells, macrophages, and epithelial cells in the gut: Implications for immune tolerance. Curr. Opin. Immunol. 20:669-675. https://doi.org/10.1016/j.coi.2008.09.007.

Salomon, C., M. Kobayashi, K. Ashman, L. Sobrevia, M. D. Mitchell, and G. E. Rice. 2013. Hypoxia-induced changes in the bioactivity of cytotrophoblast-derived exosomes. PLoS One 8:e79636. https:// doi.org/10.1371/journal.pone.0079636.

Salomon, C., M. J. Torres, M. Kobayashi, K. Scholz-Romero, L. Sobrevia, A. Dobierzewska, S. E. Illanes, M. D. Mitchell, and G. E. Rice. 2014. A gestational profile of placental exosomes in maternal plasma and their effects on endothelial cell migration. PLoS One 9:e98667. https://doi.org/10.1371/journal.pone.0098667.
Sarker, S., K. Scholz-Romero, A. Perez, S. E. Illanes, M. D. Mitchell, G. E. Rice, and C. Salomon. 2014. Placenta-derived exosomes continuously increase in maternal circulation over the first trimester of pregnancy. J. Transl. Med. 12:204. https://doi.org/10.1186/14795876-12-204.

Schild, H., and H.-G. Rammensee. 2000. gp96-The immune system's Swiss army knife. Nat. Immunol. 1:100-101.

Schneider, A., C. Krüger, T. Steigleder, D. Weber, C. Pitzer, R. Laage, J. Aronowski, M. H. Maurer, N. Gassler, W. Mier, M. Hasselblatt, R. Kollmar, S. Schwab, C. Sommer, A. Bach, H. G. Kuhn, and W.R. Schabitz. 2005. The hematopoietic factor G-CSF is a neuronal ligand that counteracts programmed cell death and drives neurogenesis. J. Clin. Invest. 115:2083-2098. https://doi.org/10.1172/ JCI23559.

Schröder, M., R. Schäfer, and P. Friedl. 1997. Spectrophotometric determination of iodixanol in subcellular fractions of mammalian cells. Anal. Biochem. 244:174-176. https://doi.org/10.1006/ abio.1996.9861.

Sordillo, L. M., and V. Mavangira. 2014. The nexus between nutrient metabolism, oxidative stress and inflammation in transition cows. Anim. Prod. Sci. 54:1204-1214.

Sordillo, L. M., and W. Raphael. 2013. Significance of metabolic stress, lipid mobilization, and inflammation on transition cow disorders Vet. Clin. North Am. Food Anim. Pract. 29:267-278. https://doi org/10.1016/j.cvfa.2013.03.002

Tauro, B. J., D. W. Greening, R. A. Mathias, H. Ji, S. Mathivanan, A. M. Scott, and R. J. Simpson. 2012. Comparison of ultracentrifugation, density gradient separation, and immunoaffinity capture methods for isolating human colon cancer cell line LIM1863-derived exosomes. Methods 56:293-304. https://doi.org/10.1016/j. ymeth.2012.01.002

Taylor, D. D., and C. Gercel-Taylor. 2008. MicroRNA signatures of tumor-derived exosomes as diagnostic biomarkers of ovarian cancer. Gynecol. Oncol. 110:13-21. https://doi.org/10.1016/j. ygyno.2008.04.033.

Thering, B. J., M. Bionaz, and J. J. Loor. 2009. Long-chain fatty acid effects on peroxisome proliferator-activated receptor-alpharegulated genes in Madin-Darby bovine kidney cells: Optimization of culture conditions using palmitate. J. Dairy Sci. 92:2027-2037. https://doi.org/10.3168/jds.2008-1749.

Théry, C., S. Amigorena, G. Raposo, and A. Clayton. 2006. Isolation and characterization of exosomes from cell culture supernatants and biological fluids. Pages 3.22.1-3.22.29 in Current Protocols in Cell Biology. 30:3.22. Wiley, Hoboken, NJ.

Théry, C., M. Ostrowski, and E. Segura. 2009. Membrane vesicles as conveyors of immune responses. Nat. Rev. Immunol. 9:581-593. https://doi.org/10.1038/nri2567.

Thomou, T., M. A. Mori, J. M. Dreyfuss, M. Konishi, M. Sakaguchi, C. Wolfrum, T. N. Rao, J. N. Winnay, R. Garcia-Martin, S. K Grinspoon, P. Gorden, and C. R. Kahn. 2017. Adipose-derived circulating miRNAs regulate gene expression in other tissues. Nature $542: 450-455$

Welton, J. L., S. Khanna, P. J. Giles, P. Brennan, I. A. Brewis, J. Staffurth, M. D. Mason, and A. Clayton. 2010. Proteomics analysis of bladder cancer exosomes. Mol. Cell. Proteomics 9:1324-1338. https://doi.org/10.1074/mcp.M000063-MCP201.

White, H. M., S. L. Koser, and S. S. Donkin. 2012. Gluconeogenic enzymes are differentially regulated by fatty acid cocktails in MadinDarby bovine kidney cells. J. Dairy Sci. 95:1249-1256. https://doi. org/10.3168/jds.2011-4644.

Zhou, X., R. Ringseis, G. Wen, and K. Eder. 2015. The pro-inflammatory cytokine tumor necrosis factor $\alpha$ stimulates expression of the carnitine transporter OCTN2 (novel organic cation transporter 2) and carnitine uptake via nuclear factor- $\mathrm{B}$ in Madin-Darby bovine kidney cells. J. Dairy Sci. 98:3840-3848. https://doi.org/10.3168/ jds.2014-9044. 